\title{
Retningslinjer påvirker ikke sykmeldingsomfanget
}

\author{
I 2007 ble det innført nye retningslinjer for sykmelding i både Norge og Sverige. Sykmeldingsomfanget \\ er imidlertid ikke vesentlig endret i de to landene etter dette. Diskusjoner legene imellom og samtalen \\ mellom lege og pasient synes å bety mer for beslutningen om å sykmelde eller ikke enn retningslinjene.
}

En undersøkelse utført i Sverige i 1995 (1) og i England i 2002, evaluert i 2008 (2), viste at effekten av daværende sykmeldingsretningslinjer var kortvarig og at de ikke påvirket langtidssykefraværet.

Nye retningslinjer for sykmelding ble innført i 2007 i både Norge og Sverige $(3,4)$. Den norske sykmeldingsblanketten ble endret fra 2008. Endringen gjorde det enklere for legene å gi råd om samhandling mellom pasient og arbeidsgiver (5). I Sverige innførte man et «beslutsstöd», som består av 110 anbefalinger - blant annet om varigheten på sykmelding for de forskjellige medisinske tilstander (6). Nedenfor diskuteres norske og svenske legers erfaringer med retningslinjene, basert på tilgjengelig del av litteraturen.

\section{Erfaringer fra før retningslinjene}

En kvalitativ studie med 26 svenske leger viste at flertallet av gruppen var oppgitt over sykmeldingsarbeidet og fryktet at de bidro til unødvendige sykmeldinger (7). Svak tilrettelegging av helsetjenesten gjorde det vanskelig å håndtere sykmeldingsspørsmål, syntes de. I en annen kvalitativ svensk studie var det store forskjeller når det gjaldt pasientenes sykdomsoppfatning og legenes funn og forståelse (8). Legene opplevde at en sykmelding kunne ha negativ effekt på en sykdomsprosess. I en tredje studie rapporterte svenske allmennleger om vansker med å vurdere nedsatt arbeidsevne, varighet og omfang av en sykmelding og det å skulle forlenge en sykmelding som var utstedt av en kollega (9).

Hos norske allmennleger var det ikke forskjell i sykmeldingsfrekvens selv om legene hadde forskjellige holdninger til sosiopolitiske og faglige spørsmål (10). Et randomisert forsøk med allmennleger viste at en intervensjon som besto i opplæring på seminar, ikke hadde effekt på den totale sykmeldingshyppigheten eller på hyppigheten av henvisning til frivillig rehabilitering (11). I en annen undersøkelse var kliniske og demografiske forhold og pasientens egenvurdering viktig for vurdering av prognosen (12).

\section{Hjelper det med retningslinjer?}

En tverrsnittsstudie fra Norge og Sverige, publisert i 2012, omfattet 3949 svenske (data fra 2008) og 221 norske (data fra 2010) allmennleger (13). Sykmelding var en hyppig problemstilling. Over halvparten av legene i begge land opplevde dette som vanskelig arbeid.

Omforente vurderingsmåter for arbeidsevne i forhold til sykdom foreligger ikke. Ett år etter at man i Sverige hadde innført retningslinjer for sykmelding, ble alle svenske leger spurt om deres bruk av retningslinjene. Spørreundersøkelsen ( $N=36989$, besvart av $61 \%$ av alle svenske leger) viste at $76 \%$ av

\section{«Det totale omfanget av sykmelding var som før»}

allmennlegene brukte retningslinjene. $65 \%$ av dem anga at de ga nyttig veiledning ved direkte pasientkontakt, $44 \%$ at de var hensiktsmessige ved samhandling med saksbehandlere i sosialtjenesten og i forsikringsselskapene. $32 \%$ fremholdt at retningslinjene bedret deres vurderingskompetanse (14).

I en annen svensk studie, som omfattet 475 sykmeldinger i 2007 og 501 sykmeldinger i 2009, ble det konkludert med at det hadde skjedd en kvalitetsforbedring av legenes vurderinger fra 2007 til 2009 (15). Vurderingsprinsippene fra International Classification of Functioning (ICF) ble tydeligere brukt (16). Men bare en tredel av legeerklæringene inneholdt slike vurderinger. En liknende undersøkelse blant svenske psykiatere viste at de i større grad fant retningslinjene vanskelig å anvende (17).

I 2011 rapporterte 2516 svenske allmennleger (18) tilsvarende problemer som i $2007(7,9)$. I tillegg var det en tendens til forlengelse av sykmeldinger på grunn av lang ventetid på supplerende undersøkelser i spesialisthelsetjenesten. Yngre leger og mannlige leger, arbeidsmedisinere, psykiatere og allmennleger forlenget sykmeldingene utover anbefalt tid i høyere grad enn andre leger (19). Begrunnelsen var hensynet til pasienten.

En gjennomgang fra Försäkringskassan i Sverige i 2009 viste at bruken av retningslinjene hadde økt hos legene så vel som hos de ansatte i forvaltningen (20). Det ble hevdet at sykmeldingsperiodene var blitt kortere og at det var mindre spredning $i$ varighet. Vurderingen av sykmeldingene var blitt mer enhetlige etter at retnings- linjene kom. Det totale omfanget av sykmelding var som før.

Kvaliteten på opplysningene i sykmeldingene varierte. Etter innføring av retningslinjer fant man flere relevante opplysninger i sykmeldingene fra svenske allmennleger enn i sykmeldinger fra øvrige legegrupper (21), men det påvirket ikke sluttresultatet målt i omfang av sykmelding.

I en kvalitativ analyse av ni fokusgruppeintervjuer med 48 norske allmennleger fra 2011 var temaene diagnostisk praksis og vurdering av arbeidsevnen hos pasienter med subjektive helseplager (22). Legenes erfaringer var at sykmeldingsspørsmål i denne pasientgruppen var svært krevende. De opplevde det som at sykmeldingsprosessen delvis var pasientledet, men at jo bedre legen kjente pasienten og jo mer erfaring legen hadde, desto riktigere syntes vurderingen av sykmeldingsbehovet å bli. De offentlige retningslinjene ble tillagt liten betydning.

En paneldatastudie fra norske kommuner for perioden 2002-10 viste at sykefraværet gikk ned med $2 \%$ dersom andelen med gradert sykmelding økte med $1 \%$. Det diskuteres om dette var en effekt av gradering i tråd med retningslinjene, eller om det skyldtes andre, lokale tiltak (23).

En norsk studie viste at det var bedre for sykmeldingsvurderingen å ha nær dialog med pasienten enn å bruke faglige retningslinjer og ytterligere medisinsk dokumentasjon (24). Studien viste også at sykmeldingsprognosen vurdert ut fra faglig dokumentasjon var mindre treffsikker enn en prognose basert på direkte kommunikasjon med pasienten.

I flere europeiske land har man hatt tilsvarende erfaringer som i Norge og Sverige $(25,26)$.

\section{Oppsummering}

For norske og svenske leger var sykmelding vanskelig arbeid, og bruken av retningslinjer i den kliniske hverdag var svært begrenset. De omtalte studier viste at retningslinjer for sykmelding hadde begrenset - om noen effekt på sykefraværet i begge land.

Jeg takker Søren Brage og Bjørgulf Claussen for verdifulle råd under arbeidet med manuskriptet.

\section{Dag Brekke}

da-bre@online.no 
Dag Brekke (f. 1945) er spesialist i samfunnsmedisin, i allmennmedisin og $i$ arbeidsmedisin. Han er tidligere distriktslege, kommunelege, rådgivende trygdeoverlege og overlege ved Sunnaas Sykehus, nå pensjonist med bistilling. Han forsker på langtidssykmeldte.

Forfatter har fylt ut ICMJE-skjemaet og oppgir ingen interessekonflikter.

\section{Litteratur}

1. Englund L, Tibblin G, Svärdsudd K. Effects on physicians' sick-listing practice of an administrative reform narrowing sick-listing benefits. Scand J Prim Health Care 2000; 18: 215-9.

2. Roope R, Parker G, Turner S. General practitioners' use of sickness certificates. Occup Med (Lond) 2009; 59: 580-5

3. Sykmelding. En håndbok i hvordan sykmelde. Oslo: Nav, 2011.

4. Försäkringsmedicinskt beslutsstöd - vägledning för sjukskrivning. Stockholm: Socialstyrelsen, 2007.

5. Andersen EJ. Ny sykmeldingsblankett fra 1. september. Tidsskr Nor Legeforen 2008; 128: 1704-5.

6. Kvanvik M. Fikk innblikk i svensk sykelønnsordning og sykmeldingspraksis. Tidsskr Nor Legeforen 2010; 130: 310

7. von Knorring M, Sundberg L, Löfgren A et al. Problems in sickness certification of patients: a qualitative study on views of 26 physicians in Sweden. Scand J Prim Health Care 2008; 26: 22-8.

8. Engblom M, Alexanderson $K$, Englund $L$ et al. When physicians get stuck in sick-listing consultations: a qualitative study of categories of sicklisting dilemmas. Work 2010; 35: 137-42.

9. Löfgren A, Hagberg J, Arrelöv B et al. Frequency and nature of problems associated with sickness certification tasks: a cross-sectional questionnaire study of 5455 physicians. Scand J Prim Health Care 2007; 25: 178-85.

10. Gulbrandsen P. Hofoss D, Nylenna M et al. General practitioners' relationship to sickness certification. Scand J Prim Health Care 2007; 25: 20-6.

11. Osterås N, Gulbrandsen P, Kann IC et al. Structured functional assessments in general practice increased the use of part-time sick leave: a cluster randomised controlled trial. Scand J Public Health 2010; 38: 192-9

12. Reiso H, Gulbrandsen P, Brage S. Doctors' predic tion of certified sickness absence. Fam Pract 2004: 21: 192-8.

13. Winde LD, Alexanderson K, Carlsen B et al. General practitioners' experiences with sickness certification: a comparison of survey data from Sweden and Norway. BMC Fam Pract 2012: 13: 10.

14. Skånér $Y$, Nilsson $G H$, Arrelöv B et al. Use and usefulness of guidelines for sickness certification: results from a national survey of all general practitioners in Sweden. BMJ Open 2011; 1: e000303.

15. Nilsing E, Söderberg E, Öberg B. Sickness certificates in Sweden: did the new guidelines improve their quality? BMC Public Health 2012; 12: 907.

16. International Classification of Functioning. Disability and Health. WHO 2001. Resolution WHA 54.21. Norsk utgave. Trondheim: Sosial- og helsedirektoratet, 2003

17. Nilsson GH, Arrelöv B, Lindholm $\mathrm{C}$ et al. Psychiatrists' work with sickness certification: frequency, experiences and severity of the certification tasks in a national survey in Sweden. BMC Health Serv Res 2012; 12: 362

18. Engblom M, Nilsson G, Arrelöv B et al. Frequency and severity of problems that general practitioners experience regarding sickness certification. Scand J Prim Health Care 2011; 29: 227-33.

19. Bränström R, Arrelöv B, Gustavsson $C$ et al. Reasons for and factors associated with issuing sickness certificates for longer periods than necessary: results from a nationwide survey of physicians. BMC Public Health 2013; 13: 478

20. Uppföljning och kvalitetsutveckling av försäkringsmedicinskt beslutsstöd. 004363-2010 SD-FD. Socialstyrelsen och Försäkringskassans gemensamma lägesrapport om utvecklingen under 2009 Stockholm: Socialstyrelsen, 2009: 21.

21. Söderberg E, Alexanderson K. Sickness certificates as a basis for decisions regarding entitlement to sickness insurance benefits. Scand J Public Health 2005; 33: 314-20.

22. Nilsen S, Werner EL, Maeland S et al. Considerations made by the general practitioner when dealing with sick-listing of patients suffering from subjective and composite health complaints. Scand J Prim Health Care 2011; 29: 7-12.

23. Kann IC, Brage S, Kolstad A, Nossen JP, Thune O. Har gradert sykmelding effekt på sykefraværet? Arbeid og Velferd nr. 2/2012. Oslo: Arbeids- og velferdsdirektoratet, 2012: 10.

24. Fleten N, Johnsen R, Førde OH. Length of sick leave - why not ask the sick-listed? Sick-listed individuals predict their length of sick leave more accurately than professionals. BMC Public Health 2004; 4 : 46

25. Wynne-Jones G, Mallen CD, Welsh V et al. Rates of sickness certification in European primary care: a systematic review. Eur J Gen Pract 2008: 14: 99-108.

26. Letrilliart L, Barrau A. Difficulties with the sickness certification process in general practice and possible solutions: a systematic review. Eur J Gen Pract 2012; 18: 219-28.

Mottatt 17.6. 2014, første revisjon innsendt 14.7. 2014, godkjent 24.10. 2014. Redaktør: Trine B. Haugen.

Publisert først på nett. 